\title{
SISTEM PENGUPAHAN KULI PERKEBUNAN TEMBAKAU DI SUMATERA TIMUR PADA MASA KOLONIAL
}

\author{
Oleh: \\ Dyna Ronauli Hutagaol \\ Lister Eva Simangunsong
}

\begin{abstract}
ABSTRAK
Penelitian ini bertujuan untuk mengetahui sistem pengupahan yang berlaku bagi kuli pada perkebunan tembakau di Deli Sumatera Timur, bentuk-bentuk perlakuan para penguasa terhadap kuli di Deli Sumatera, dan dampak sistem pengupahan terhadap kehidupan para kuli perkebunan tembakau di Deli Sumatera Timur pada masa Kolonial. Untuk memperoleh data yang diperlukan digunakan metode penelitian kepustakaan (library research). Hasil penelitian menunjukkan bahwa Perkembangan menjadi daya tarik tersendiri bagi pihak lain yang berkeinginan menanamkan modalnya di Deli. Sistem pengupahan borongan yang diterapkan oleh tuan kebun semata-mata hanya untuk menguntungkan mereka saja. Para kuli justru sangat menderita dengan sistem ini, karena dengan upah 35 sen dalam 10 jam bekerja sangat tidak cukup untuk memenuhi kebutuhan hidup mereka. Lain hal jika tuan kebun melakukan pemotongan upah ketika kuli mendapat hukuman, dan biaya pengeluaran alat yang akan digunakan kuli dalam bekerja yang diterapkan dalam sistem upah borongan ini semuanya ditanggung oleh kuli. Hal ini membuat kehidupan para kuli menjadi semakin sulit, karena untuk kebutuhan hidupnya sehari-hari saja mereka harus bekerja keras dengan jaminan nyawa mereka sendiri yang mereka pertaruhkan.
\end{abstract}

Kata Kunci: Upah, Kuli kebun, Kolonialisme. 


\section{PENDAHULUAN}

Pada masa kolonial Sumatera Timur merupakan wilayah di Pulau Sumatera yang mengalami eksploitasi besar-besaran oleh pihak swasta terutama dalam pengembangan perkebunan. Pembukaan hutan-hutan, penanaman tanaman komoditi, mengalirnya investasi dalam jumlah besar ke wilayah ini dan pencarian tenaga kerja dari luar negeri untuk mendukung eksploitasi perkebunan sehingga Sumatera Timur berkembang pesat dan menjadi wilayah yang penting di Sumatera.

Eksploitasi lahan oleh pihak onderneming atas beberapa wilayah tertentu memiliki pengaruh yang berbeda pula terhadap sisi kehidupan penduduk yang berada di luar onderneming, karena eksploitasi besar-besaran yang dilakukan pihak onderneming mengakibatkan berkurangnya lahan pertanian penduduk. Pembukaan perkebunan tembakau yang baru di wilayah ini melibatkan kepentingan yang bermula dari masalah hak penggunaan tanah untuk kepentingan perkebunan swasta Belanda yang sebenarnya merupakan tanah milik rakyat dan sultan.

Pembukaan perkebunan tembakau dimungkinkan apabila sultan memberi hak konsesi pengusahaan tanah atas kesepakatan. Akan tetapi pada kenyataannya, pembukaan perkebunan itu hanya melibatkan pengusaha perkebunan dan pihak sultan tanpa musyawarah dengan para datuk sebagai kepala kampung diwilayah ini. Rasa hormat dan toleransi yang dinikmati Raja-raja ini sebelumnya telah berangsur-angsur hilang, dan rakyat mulai berpikir bahwa Raja-raja ini telah mendapatkan kekuasaannya sebagai akibat dari Politik Kontrak (sesungguhnya inilah yang telah memberi kekuasaan itu, bukan kecintaan dan kasih sayang rakyatnya), yang melahirkan raja-raja hartawan namun bukan pemimpin yang bijaksana .

Selain itu, penggajian/pengupahan para kuli juga menjadi permasalahan yang besar di Deli. Dalam sebulan para kuli menerima upah sebanyak dua kali, dengan harihari tertentu. Dengan upah sebesar dua sampai dua setengah dolar sebulan, para kuli harus berusaha bagaimana agar upah yang mereka terima itu cukup untuk kehidupan sehari-hari. Hal ini belum termasuk pengurangan upah, ketika buruh melakukan kesalahan dalam pekerjaannya, upah mereka akan dipotong. Sistem pengupahan ini 
menjamin Tuan kebun, bahwa para kuli bekerja maksimal, baik dalan intensitas maupun dalam jangka waktu bekerja. Untuk memperoleh penghasilan minimum, para kuli harus mencurahkan perhatian penuh pada tanamannya. Tidak jarang mereka harus bekerja jauh lebih lama dari sepuluh jam yang ditetapkan dalam kontrak.

Pada dasarnya, kontrak-kontrak ini disertai ancaman Peonale Sanctie (aturan hukum bagi kuli yang bekerja di perkebunan) yang dibuat oleh pemerintah kolonial Belanda pada 1879 di wilayah tersebut. Bahkan selain itu banyak penindasan dilakukan oleh pengusaha perkebunan tembakau di Deli terhadap para kuli perkebunan (koeli kontrak). Selain Peonale Sanctie yang dikeluarkan pemerintah Belanda, untuk mengatur para kuli ini dikeluarkan pula Koeli Ordonatie sebagai sarana pengusaha untuk memaksa buruh-buruh kontrak agar tetap tinggal di perkebunan.

Kuli yang ada di perkebunan Deli Sumatera Timur memiliki kehidupan yang cukup teratur bahkan bisa dikatakan memiliki kehidupan yang monoton. Segala kegiatan dilakukan tanpa boleh keluar dari lingkungan perkebunan yang dijaga dengan ketat. Dengan konsekuensi apabila para buruh diketahui melarikan diri maka mereka akan dicari dengan cara apapun oleh penjaga. Apabila sampai ditemukan melarikan diri maka para kuli akan dihukum dan diserahkan kepada tuan kebun untuk menerima hukuman cambuk, dipukul dan ditendang. Derita-derita kuli kebun yang berbagai ragam tidak lagi dapat dibuat catatannya, kebanyakan sudah disimpan menjadi rahasia kebun.

Maka dari hal diatas dapat dilihat bahwa tindakan yang semena-mena para tuan kebun secara sadar atau tidak dibenarkan oleh pemerintah kolonial Belanda yang ada di Deli pada saat itu. Kehidupan dan penindasan yang dialami para kuli perkebunan inilah yang membuat peneliti tertarik untuk menulis tentang "Sistem pengupahan kuli perkebunan Tembakau di Sumatera Timur pada masa kolonial ", yaitu tentang kehidupan para buruh yang disebut koeli kontrak, dengan segala derita, penindasan yang dialami serta penipuan yang mengakibatkan kemarahan para kuli dan potret kehidupannya. 
Berdasarkan uraian diatas maka peneliti tertarik untuk meneliti tentang Sistem Pengupahan Kuli Perkebunan Tembakau di Sumatera Timur Pada Masa Kolonial. Adapun yang menjadi rumusan masalahnya yaitu : 1. Bagaimana latar belakang sistem pengupahan yang diberlakukan di Sumatera Timur pada masa Kolonial, 2. Bagaimana pelaksanaan dari sistem upah yang terjadi di Sumatera Timur pada masa Kolonial, 3. Bagaimanakah dampak sistem pengupahan terhadap kehidupan Kuli perkebunan. Dalam penelitian ini penulis menggunakan metode penelitian kepustakaan (library research).

\section{PEMBAHASAN}

\section{A. Latar Belakang Sistem Pengupahan Kuli}

Pada saat Deli diperintah oleh Sultan Mahmud Perkasa Alam (1858-1872), kesultanan Deli telah menandatangani perjanjian dengan pemerintah Belanda pada tahun 1862. Pada saat itu Belanda dibawah pimpinan Residen Riau Eliza Netscher datang ke Deli dan membuat perjanjian Acte Van Verband. Peristiwa ini terjadi pada tanggal 22 Agustus 1862 diatas kapal perang Reinier Claassen. Labuhan yang merupakan ibukota Deli pada saat itu dijadikan sebagai basis kekuatan Belanda dan menempatkan 'kontrolir' Cats de Raet disana.

Pada tahun 1864 merupakan tahap memperkenalkan tanaman tembakau Deli, dimana pelopornya adalah Nienhuys. Kemudian pada tahun 1869 baru dibuka kebun baru di Sunggal dan pada 1875 di Sungai Besar dan Kelumpang. Pada tahun 1868 saja sudah memperoleh keuntungan yang sangat besar, sehingga berduyun- duyun maskapai- maskapai asing lainnya menanam tembakau di daerah ini. Pada 1866 dibuatlah perkongsian antara tuan- tuan Janssen- P.W.Clemen dan Nienhuys dengan kapital pertama \$. 10.0000,-. Lalu didatangkanlah kuli- kuli Cina dan India dari Penang dan dibentuklah Deli Maatschappij yang kemudian diperkuat dengan tibanya tuan Cremer yang merupakan pribadi yang terkemuka dan membuat perkebunan tembakau berkembang pesat. 
Setelah Nienhuys menetap tinggal di Deli, ia juga berhasil mendapatkan konsesi tanah dari Sultan Mahmud Perkasa Alamsyah untuk membuka perkebunan tembakau di tanah Deli ini. Nienhuys diberi hak pemakaian lahan (konsesi) selama 20 tahun tanpa perjajian sewa. Selama 5 tahun pertama dia dibebaskan dari pembayaran pajak dan sesudah itu baru membayar 200 gulden setahun. Daerah konsesi untuk penanaman tembakau pertama letaknya di tepi sungai Deli. Lokasinya berada di Tanjung Sepassi seluas 4.000 bau ( 1 bau = 7,096.5 meter persegi/1 bahu = 0,74 ha) dan sejak itulah bermula sejarah perkebunan tembakau di tanah Deli.

Pada awalnya pengusaha perkebunan pertama Nienhuys, berpendapat bahwa tanah-tanah di Sumatera Timur hanya mampu menghasilkan panen tembakau untuk satu kali panen saja. Setelah diadakan penelitian pada awal tahun 1890, tembakau gulung yang bermutu baik dapat pula dihasilkan di atas lahan kosong yang pernah ditumbuhi tembakau. Lahan yang pernah digunakan terlebih dahulu dikosongkan selama masa 8 (delapan) tahun atau 12 tahun yang bertujuan untuk mengembalikan kesuburan tanah.

Tembakau yang dihasilkan dari tanah yang telah dikosongkan ternyata bermutu baik, walaupun warna daunnya lebih muda daripada tembakau yang berasal dari tanah hutan. Pengolahan tanaman dilakukan di bawah pengawasan seorang administrator dengan bantuan 4 (empat) atau 6 (enam) orang asisten. Lahan yang diolah adalah 400 petak tembakau, setiap petak berukuran 1 bau yang akan di tanami 16.000 batang pohon tembakau. Setelah dipanen daun-daun tembakau tersebut diserahkan kepada pihak perusahaan. Daun-daun tembakau akan dipilah, dihitung dan dinilai oleh asisten kebun. Daun tembakau yang diolah sebagai pembungkus cerutu hanya daun tembakau yang benar-benar berkualitas baik.

\section{B. Langkanya Tenaga Kerja Dan Masuknya Kuli Perkebunan Ke Deli}

Dengan semakin berkembangnya perkebunan, maka pihak pengusaha Onderneming sudah tentu membutuhkan tenaga kerja lebih banyak lagi. Akibat dari terbentuk dan berkembangnya perkebunan-perkebunan tersebut adalah munculnya 
masalah kelangkaan tenaga kerja kuli yang semakin meningkat di perkebunan Sumatera Timur. Perkembangan perusahaan-perusahaan asing di Sumatera Timur sangat memerlukan tenaga kerja manusia. Pembukaan hutan lebat, pebuatan saluran air, pengelolaan tanah penanaman tembakau dan sebagainya sangat memerlukan tenaga manusia. Sulitnya mencari tenaga kerja sudah diketahui sejak semula. Para pengusaha perkebunan mengetahui penduduk asli tidak bersedia bekerja di perkebunan, mereka juga kurang terampil dalam pertembakauan. Akhirnya mereka tergantung pada kuli yang didatangkan dari luar, berawal dari kuli Cina lalu kuli Jawa.

Pada permulaannya untuk perkebunan sangat sukar sekali diperoleh kuli-kuli. Pada masa tuan Nienhuys, ia mengusahakan mencari kuli-kuli orang Tionghoa ketanah seberang (Penang), sebab kuli-kuli yang dipakainya ketika itu yang terdiri dari orangorang Batak sangat tidak memuaskan. Didapati kuli-kuli orang Tionghoa dan VoorIndiers (ketika itu namanya orang keling). Di Pulau Pinang mereka ini pun menerima penawaran dari Nienhuys dan dijanjikan dengan pemberian gaji yang besar, namun setelah mereka sampai di tanah Deli gajinya hanya beberapa ringgit saja. Menurut keterangan, inilah sebab banyak kuli-kuli yang melarikan diri. Mereka kemudian membujuk tauke-tauke Cina (kuli Cina yang sudah lama tinggal di Deli) yang terlebih dahulu diberi uang suap untuk berangkat ke Cina agar dapat membujuk bangsanya menjadi 'kuli kontrak' di Deli. Kiranya usaha ini membawa hasil, terlihat dari banyaknya kuli Cina yang datang ke Deli.

Untuk mengatasi masalah tenaga kerja yang semakin banyak maka pengusahapengusaha perkebunan semakin giat pula mencari tenaga kerja. Jadi selain tetap mendatangkan kuli-kuli langsung dari Cina, pengusaha-pengusaha tersebut kemudian mendatangkan kuli dari Jawa pula. Dengan alasan bahwa pekerja-pekerja dari Jawa ini rajin dan tahan bekerja. Para pengusaha perkebunan tembakau di Sumatera Timur sudah mengetahui bahwa para pekerja Jawa ini adalah pekerja-pekerja yang memiliki ketrampilan dalam bidang pertanian cukup tinggi sehingga mereka mudah menyesuaikan diri dengan bekerja diperkebunan. 
Para makelar mencari tenaga kerja dengan cara memberikan janji-janji muluk. Mereka mengatakan hal yang sama dengan kuli Cina yang di mereka Cari di Penang, dengan mengatakan bahwa di Deli sangat mudah mendapatkan uang dan semuanya mendapatkan rumah. Selain itu, makanan disana enak-enak dan setiap hari besar diadakan permainan judi dan pegelaran wayang kulit. Namun semua hal itu tidaklah sesuai dengan kenyataan yang seperti mereka harapkan, justru sebaliknya.

\section{Pelaksanaan Sistem Pengupahan Kuli Perkebunan Tembakau}

Sistem kontrak kerja mencapai bentuknya yang khusus pada perkebunan besar di Sumatera Timur. Yang dimaksud khusus disini bahwa sistem kontrak kerja di perkebunan Sumatera Timur melibatkan ribuan kuli kontrak dari Jawa dan sangat ditupang oleh modal besar perusahaan perkebunan Eropa. Dalam pada saat itu sistem kesukuan masyarakat Sumatera Timur telah berubah secara mendasar. Para migran Jawa dan keturunannya, yang kemudian disebut 'JaDel' (Jawa-Deli), telah menjadi salah satu penunjang pokok kehidupan ekonomi perkebunan besar di Sumatera Timur. Dari hal diatas, tampaknya para petani kecil Jawa yang merupakan cikal bakal kuli kontrak dan berkoloni di perkebunan Sumatera Timur, merupakan pekerja yang mencari upah lepas, yang kemungkinan besar kehidupan ekonominya di Jawa semakin sulit.

Untuk sistem pengupahan yang terjadi di perkebunan tembakau Deli, sebagian besar kuli perkebunan menerima upah dalam bentuk upah borongan atau upah per potong. Upah harian dan bulanan pun dasarnya adalah jumlah prestasi yang telah ditetapkan sebelumnya dan harus diselesaikan sebelum habis waktunya. Seluruh proses budi daya tembakau, seluruh pekerjaan orang Cina dalam menyiapkan ladang, menanam, merawat dan memanen tembakau dilaksanakan dengan cara borongan, dan uang borongan itu dibayarkan sebagai ganti upah bulanan .

Sistem kerja borongan ditambah dengan pengawasan yang keras menjadi ciri disiplin kerja di perkebunan tembakau pada tahap kapitalisme awal. Berbagai pelanggaran yang diakibatkan oleh praktek kerja borongan segera mendapat perhatian 
dari Protector Of Chinese di Malaka yang sangat berjasa dalam mengerahkan tenaga kuli cina. Dalam sebuah laporan resmi pada 1881, Protector mengeluhkan rendahnya tingkat upah, samarnya cara menghitung upah kerja, dan tentang praktek terlarang bagi para pengawas di Sumatera Timur. Namun, sia-sia Protectormendesak pemerintah kolonial Belanda agar memberlakukan upah bulanan.

Tuan kebun menyatakan upah bulanan akan kurang mendorong kuli yang baik, sementara kuli yang tak baik akan lebih terdorong lalai bekerja. Tak jarang tuan kebun juga menipu kuli dengan tidak memberikan kebebasan membelanjakan upahnya yang sudah rendah itu. Banyak perkebunan menggaji kulinya sebagian dengan uang buatan sendiri berupa kertas bon atau keping logam yang hanya dapat dibelanjakan di toko (kedai) milik perkebunan. Menurut para tuan kebun, mereka telah mengeluarkan alat tukar karena ada kekurangan mata uang kecil di Sumatera Timur. Satu dollar terdiri atas 100 kupang atau 1000 duit, dan keduanya itu disebut duit.

Uang dolar buatan tuan kebun tersebut merupakan salah satu tipu muslihat untuk mendapatkan dolar dan mata uang yang diperlukan. Selain itu, hal tersebut dilakukan oleh tuan kebun untuk tetap menjaga agar uang yang dimiliki oleh kuli hanya beredar di dalam perkebunan. Jika seorang kuli bekerja di perkebunan Bindjai digaji dengan uang Kebon Bindjai maka uangnya itu tidak dapat dibelanjakannya ke perkebunan Serdang atau di kota Medan. Benar-benar menindas, orang punya uang tapi tidak bisa dibelanjakan di tempat lain.

Sistem ini sangat merugikan kuli tentunya, karena pemimpin perusahaan masih memotong jumlah keseluruhan terakhir untuk menutupi beberapa pengeluarannya. Pertama-tama adalah biaya membersihkan lahan dan lain-lain kegiatan untuk menyiapkan ladang tembakau. Ditaksir nilainya lima sampai sepuluh dolar. Lalu, kuli harus membiayai sendiri alat yang digunakannya dan penggantian alat-alat tersebut. Sampai-sampai, papan berita diruang tidur dan buku kecil untuk mencatat upah dan uang muka para kuli harus dibayar oleh kuli itu sendiri.

Dengan sistem borongan itu pemimpin perusahaan hendak memberi gambaran palsu seolah-olah ia mempekerjakan petani tembakau dengan tanggungan dan resiko 
sendiri dan dibantu dengan tenaga tambahan yang belum berpengalaman, juga barang dengan keperluan lain. Akibat dari berbagai pemotongan itu, pendapatan bersih seorang kuli ladang dalam satu masa tanam (kira-kira delapan bulan) tak mungkin lebih dari 75 dolar. Karena pekerjaan dibangsal peragian sesudah masa ladang juga dibayar rendah, maka kuli yang paling berpengalaman pun pada sekitar pertukaran abad ini rata-rata hanya dapat menerima tak lebih dari 100 dolar/tahun.

Menurut saya, cara kerja ini menyebabkan konflik diantara sesama kuli jadi lebih terasa. Menurut tuan kebun, diperkenalkannya secara berangsur-angsur cara petik yang lain, yaitu cara petik tiap lembar daun akan mendatangkan kenaikan upah yang tidak sedikit. Pemotongan upah adalah praktek sehari-hari, karena kuli tidak muncul atau terlambat muncul ditempat kerja, juga karena malas, tidak cakap atau bentukbentuk kelalaian lainnya dalam melaksanakan tugas.

Segera sesudah berdirinya organisasi Deli Planters Vereeniging (DPV), para anggota sepakat membayar maksimum delapan dolar untuk setiap pohon tembakau. Perkebunan yang ketika itu sudah membayar lebih dari delapan dolar( sembilan dolar untuk tembakau kualitas terbaik adalah biasa waktu itu) mendapat perintah untuk mengakhiri pelenggaran yang pada akhirnya akan mendatangkan akibat yang sangat tidak menyenangkan. Langkah itu dimaksudkan untuk mencegah naiknya upah apabila tenaga kerja sedang langka, dan siasat itu sangat berhasil. Dalam beberapa dasawarsa berikutnya jumlah cadangan kuli tertinggal dari jumlah permintaan yang terus meningkat. Waktu itu premi yang dibayarkan kepada perantara memang naik, tetapi harga tenaga kerja tidak naik.

Tergantung pada kualitasnya, sampai awal abad ke-20, harga tetap tidak lebih dari delapan dolar. Lebih dari itu, kebanyakan perkebunan justru menimpakan resiko penanaman tembakau kepada kuli ladang. Mereka melakukan pembayaran bukan atas tiap pohon tembakau yang ditanam, melainkan atas tiap pohon yang dipanen. Cuaca buruk, tanah yang kurang menguntungkan, dan berbagai keadaan lain yang tak daapat diubah oleh penanam dapat mengakibatkan naik turunnya penghasilan kuli. Hal ini dibuktikan dengan krisis tembakau gulung Deli yang berpautan dengan krisis ekonomi 
kapitalisme pada 1890 dan memaksa dikeluarkannya tarif Mc.Kinley. Aturan itu diberlakukan kepada berbagai jenis tembakau dengan tarif sebesar 35 hingga 37 sen setiap pon, tergantung kualitasnya. Meningkatnya bea impor mengakibatkan pengusaha-pengusaha tembakau Amerika hanya membeli sekitar 60.000 bal pada musim semi.

Meskipun dalam musim-musim lainnya juga ditawarkan, namun pengusahapengusaha AS membatalkan tembakau yang telah dipesan. Titik puncak panen tembakau terjadi pada 1891, ketika persediaan panen tembakau bertambah $25 \%$. Akibat krisis tembakau yang berlangsung pada 1891-1907 hampir 300 perkebunan di Sumatera Timur ditutup .

Kuli hanya mendapat upah sebanyak 35 sen dalam sehari atau f 10,50 dalam sebulan dan dari ini upah harus dipotong lagi f 2, untuk bayar persekot atau uang muka ketika kuli bekerja dan menandatangtani kontrak. Belum lagi untuk makan para kuli dan istri yang menghabiskan berkisar 14 gantang beras dalam sebulan saja.

\section{Bentuk-Bentuk Perlakuan Penguasa Terhadap Kuli Perkebunan Di Deli \\ 1. Penipuan Terhadap Para Kuli}

Cara untuk mendapatkan kuli-kuli Cina (Tionghoa) di Penang yang semakin lama semakin naik jumlahnya adalah melalui perantara makelar (broker). Broker ini mengambil kuli Cina dari Semenanjung Tanah Melayu ini tidak melalui seleksi atau penyaringan, namun dengan cara melakukan penipuan. Mereka membujuk calon pekerja itu dengan menjanjikan hal yang begitu muluk-muluk, agar mereka lebih tertarik untuk bekerja di tanah Deli.

Akibat penipuan yang dilakukan oleh para broker ini, pengusaha perkebunan mulai merasakan kekurangan pekerja-pekerja yang baik. Dan hal ini juga dirasakan oleh para pengusaha pertambangan Timah di Semenanjung Tanah Melayu. Sehingga pemerintah Inggris mengadakan sebuah biro untuk melindungi orang-orang Cina dari penipuan untuk dipekerjakan di Deli pada tahun 1876, yang dikepalai oleh pegawaipegawai yang diberi pangkat Protectors of Chinese . 
Sekalipun kuli Cina rajin dan terampil, namun biaya perekrutan mereka semakin banyak memakan biaya meski dengan ikatan kontrak. Oleh karena bea imigran baru itu membuat kuli Cina menjadi sangat mahal, pengusaha perkebunan kuli dari Jawa. Hal ini disebabkan karena kuli dari Jawa biayanya jauh lebih murah dan cara kerjanya yang sangat ulet dan rajin. Dengan demikian maksud pemerintah tercapai untuk membuka lapangan kerja bagi orang Jawa yang tidak memiliki tanah . Pemerintah Hindia-Belanda memang sengaja membuat peraturan yang menetapkan adanya bea imigran kepada setiap kuli yang didatangkan dari Cina. Dengan tujuan agar para pengusaha perkebunan Deli Sumatera Timur mengambil kuli dari pulau Jawa. Hal ini dilakukan dengan maksud agar dapat mengurangi kepadatan penduduk di pulau Jawa dan membuka lapangan pekerjaan bagi penduduk pulau Jawa yang tidak memiliki tanah.

\section{Hukuman dan Kekerasan di Deli}

Bentuk hukuman yang paling lazim adalah pemotongan upah atau penambahan kerja, yaitu untuk kuli yang tidak memperlihatkan cukup semangat kerja, tidak menjalankan perintah atau dianggap tidak tunduk. Dalam memberikan hukuman, para manejer bertindak sesuai dengan pendapat sendiri. Sebagai hukuman tambahan, kuli yang melarikan diri diwajibkan menanggung semua biaya yang telah digunakan perkebunan untuk melacak dan membawanya kembali. Dengan bertambahnya utang, imobilitas kuli kontrak pun bertambah pula. Soalnya, para kuli beranggapan bahwa mereka baru boleh meninggalkan perkebunan apabila mereka sudah tak mempunyai utang lagi. Walaupun masa kontrak lebih panjang dari yang sudah disetujui.

Tetapi karena upah yang begitu rendah, pekerjaan begitu berat, dan kehidupan begitu sulit maka manfaat ketentuan denda sebagai sanksi pun hanya terbatas kegunaannya. Lagi pula, sebagian besar sanksi bertentangan dengan ketentuan ordonansi kuli bahwa yang berhak menghukum adalah pemerintah. Sudah semenjak diberlakukannya Peonale Sanctiepara tuan kebun menuntut hak menahan sendiri kuli 
yang diduga melanggar peraturan diperkebunan sebelum ada kemungkinan mengirimkan mereka ke pengadilan.

Sesungguhnya apabila orang Belanda setia pada landasan hukumnya sendiri, tidaklah akan ada "Peonale Sanctie" dalam perjanjian kerja. Sudah menjadi ketentuan pembuat undang-undang kolonial untuk Hindia Belanda di tahun 1879 bahwa tidak boleh ada hukuman pidana bagi pribumi yang tidak memenuhi janji kerja. Namun entah dimana letaknya jalan pikiran Belanda menjadi berobah begitu saja untuk malangkahi ketentuan dasar ini. Padahal lahirnya pun sudah lama ditarik kebebasan tuan-tuan kebun di Deli untuk menjadi hakin sendiri dikebunnya dalam tujuan menciptakan adanya "Rule of Law" di kebun Sumatera Timur. Hal ini terjadi diakibatkan oleh adanya Peonale Sanctie yang lahir karena adanya kebijaksanaan Agrarische Wet tahun 1870 yang berimplikasi pada ketersediaan lahan perkebunan yang sangat besar. Untuk menjamin perusahaan ini mendapat kuli yang tetap dapat melakukan pekerjaan, maka didalam pasal 2 no. 26 Algement Politie Strafeglementvoor Inlandersatau disingkat APSI dapat memberikan satu-satunya jaminan kepada kaum kuli, supaya kaum pekerja setia menuruti bunyi kontrak .

Menurut saya pejabat pada masa itu telah bekerja sama untuk melegalkan hukum kekerasan dalam APSI sehingga apa yang dilakukan tuan kebun kepada para kuli menjadi legal ataupun sah untuk diterapkan. Sehingga kuli tidak mampu untuk menentang ataupun menolak perlakuan kasar para tuan kebun. Kalau kuli sampai menentang, maka hukuman yang diterima akan jauh lebih parah dan kejam berupa hukuman fisik seperti pemukulan, pencambukan, pengurangan jatah makan, bahkan di kenakan denda sesuai dengan peraturan yang berlaku. Baik dengan denda uang ataupun denda wajib kerja. Setelah mengalami hukuman, para pekerja tetap menjalankan pekerjaannya sebagaimana mestinya.

Pelanggaran-pelanggaran ringan diselesaikan oleh pengadilan kepolisian. Pada 1877, sebelum berlakunya Ordonansi kuli Residan Sumatera Timur sudah mengadakan persidangan khusus setiap bulan untuk menghukum kuli kontrak yang melakukan pelanggaran atas dasar pengaduan para tuan kebun. Lagi pula jika diminta, para tuan 
kebun sering menghukum kuli yang keras kepala yang tidak memperhatikan ketentuan perusahaan. Bahkan untuk membuat patuh, para kuli pernah diketahui bahwa upah kuli ditahan, tidak diberi. Mengenai kesempatan kuli boleh menyampaikan keluhan atau pengaduannya kepada penguasa yang berwenang, biasanya tidak akan diijinkan oleh tuan kebun .

Maka dari hal diatas, tindakan yang semena-mena para tuan kebun secara sadar atau tidak dibenarkan oleh pemerintah kolonial Belanda yang ada di Deli pada saat itu. Hal ini dapat dilihat dari tindakan pemerintah yang mendiamkan pengaduanpengaduan dari para kuli yang menerima ketidakadilan dan penindasan yang dilakukan oleh para tuan kebun. Disamping itu maraknya sogok menyogok yang terjadi dikalangan birokrasi pemerintahan maupun di pengadilan. Bahkan tindakan yang lagi terjadi di jajaran birokrasi, yang melindungi tuan kebun agar tidak terlibat menjadi tersangka dalam kasus yang dilaporkan oleh kuli yang akan memberatkan pihak birokrasi dalam kepemimpinannya. Demikianlah buruknya birokrasi pemerintahan dan pengadilan yang terjadi pada saat itu di Deli.

Pada waktu para pembuka perkebunan mulai membuka perkebunan di Deli, yaitu dimulai sejak jaman Nienhuys semakin tambah parah saja, main tendang dan pukul yang dilakukan dengan sesuka hati. Bahkan pada masa itu terkenal istilah 'perantaian' bagi kuli yang memberontak, yaitu diborgol dengan bandul besi berat di kaki. Hal inilah yang membuat semakin suramnya kehidupan para kuli yang hidup diperkebunan Deli pada masa itu. Menjelang berakhirnya masa kontrak, pemimpin perusahaan menekan kuli kontrak untuk memperpanjang kontrak dengan menolak memberikan surat pemberhentian. Kuli yang menolak dicambuk dan tidak diberi makan sampai akhirnya menyerah.

Dengan senjata kekuasaan itulah mereka dapat mencengkeram kuli kontrak hingga disiplin pribadi dan ketertiban umum tanpa kesulitan dapat saling menunjang. Kuli yang melanggar kontrak dibawa sebagai tawanan dan diserahkan kepada pejabat pemerintah, dan sesudah menjalani hukuman mereka dikawal pulang kembali ke perkebunan. 


\section{E. Dampak Sistem Pengupahan Dalam Kehidupan Kuli Perkebunan}

Segala kegiatan hanya dilakukan tanpa boleh keluar dari lingkungan perkebunan yang dijaga sangat ketat. Kuli akan menerima akibatnya apabila mereka diketahui melarikan diri maka mereka akan dicari bagaimana pun caranya oleh penjaga perkebunan. Dan apabila mereka sampai ditemukan, para kuli yang melarikan diri ini akan menerima hukuman berupa pukulan dan tendangan yang kasar dari para penjaga.

Selanjutnya mereka akan diserahkan kepada tuan kebun untuk menerima kembali hukuman sesuai dengan ketentuan yang diberikan tuan kebun. Biasanya hukuman yang akan mereka terima dari tuan kebun tentu lebih kejam, tidak hanya dipukul atau ditendang namun mereka akan menerima hukuman cambuk sesuai dengan kebijakan tuan kebun.

Cara lain yang digunakan adalah mendorong kuli yang habis kontraknya pada masa lumbung untuk menggunakan uang lebih banyak dari yang mereka peroleh pada bulan-bulan sebelumnya. Dalam masa ini pelacur diijinkan masuk dalam kawasan perkebunan, perjudian diberi peluang yang luas dan pemadatan pun digalakkan. Hal seperti ini lumrah terjadi di perkebunan untuk mengikat para kuli tetap tinggal dan terus bekerja di perkebunan. Karena memang, majikan dengan sengaja mengijinkan terjadinya perjudian, perdagangan candu, dan pelacuranagar disatu sisi para kuli mendapat hiburan dan merasa betah tinggal di lingkungan perkebunan. Namun disisi lain majikan membuat hal itu agar para kuli menghabiskan uangnya dan kemudian berhutang kembali kepada majikan.

Pada waktu majikan memberikan pinjaman kepada kuli, maka pinjaman (hutang) inilah yang nantinya akan mengikat para kuli untuk menandatangani kembali kontrak kerja dengan majikan untuk dapat melunasi pinjamannya(hutang) kepada majikan (tuan kebun). Dan akhirnya tercapailah tujuan yang sesungguhnya dari tuan kebun yang menginginkan para kuli untuk tetap tinggal dan bekerja di perkebunan. Untuk pemukiman yang biasanya ditempati oleh para kuli amat tidak layak untuk 
ditempati oleh manusia. Seperti dalam satu pemukiman (barak) biasa dihuni oleh 50 kuli, berdesak-desakan dan berpikiran tentang pemukiman yang layak bagi para kuli.

Sementara tingkat kesadaran akan pentingnya kesehatan amatlah sangat kurang dari para kuli. Dikarenakan dalam beberapa barak hanya memiliki satu buah jamban ( sekarang kita sebut toilet ). Tanpa disertai sumber air/mata air yang memadai untuk tempat para kuli melakukan MCK (Mandi,Cuci, Kakus) sehingga banyak dari para kuli menderita penyakit yang beraneka ragam seperti penyakit kulit, radang tenggorokan dan paru-paru dan bahkan penyakit kelamin. Penyakit ini biasanya disebabkan kurangnya menjaga kebersihan, untuk penyakit lebih disebabkan kepada seringnya para kuli, baik laki-laki maupun perempuan dalam berganti pasangan.

Dari hal diatas dapat disimpulkan bahwa pengeluaran para kuli sebenarnya lebih besar ke potongan-potongan wajib dan kepuasan pribadi dalam mencari hiburan untuk menghilangkan rasa bosan dan tertekan yang dialami para kuli dilingkungan perkebunan. Sehingga pada akhirnya, para kuli yang seharusnya bisa memenuhi kebutuhan hidupnya bahkan menabung, malah merasa kekurangan bahkan sampai berhutang. Dan hutang inilah yang kemudian menyebabkan para kuli harus menandatangani kembali kontrak kerja dengan pihak perkebunan.

\section{PENUTUP}

sistem upah di perkebunan dilakukan dengan sistem borongan, terutama untuk para pekerja ladang. Sistem ini diterapkan tuan kebun hanya untuk kepentingan mereka semata, karena hal ini hanya menguntungkan pihak penguasa pada masa itu. Sistem borongan ini, para kuli perkebunan bekerja dengan waktu yang ditentukan dan dengan hasil yang ditentukan oleh tuan kebun dalam proses pengerjaannya. Pekerja ladang bertugas sebagai penanam tembakau. Jumlah dan mutu produksi tembakau tergantung kepada pekerjaan mereka. Sistem yang diterapkan di perkebunan ini sangat merugikan para kuli, karena jika dilihat dari lamanya bekerja hingga 10 jam dalam sehari upah yang mereka terima tidak sebanding dengan jam kerja yang mereka terima. Belum lagi 
pemotongan-pemotongan lainnya yang membuat kuli harus berhutang kepada Tuan Kebun.

Seluruh proses budi daya tembakau dalam sistem borongan ini dilaksanakan oleh pekerja Cina, Jawa dan India (Sering disebut orang keling) mulai dari merawat, memanen sampai mengolah daun tembakau yang sudah dipetik (mengeringkan, meragi, dan menyortir). Semua pekerjaan itu dibayar dengan sistem borongan. Penerimaan upah yang rendah menyebabkan keadaan sosial ekonomi para pekerja sangat terpuruk.

Perilaku Tuan Kebun yang amat sangat tidak manusiawi seperti penipuan, pemukulan, penghinaan dan cara-cara yang tidak sewajarnya diterima oleh seorang manusia yang diterima oleh kuli secara berkelanjutan pada akhirnya menimbulkan perasaan tertekan dan tersiksa di hati para kuli. Penindasan yang terjadi terus menerus terhadap para kuli sulit untuk diberantas. Bahkan cenderung lebih meningkat, sebab tuan kebun berpikir kalaupun menghukum kuli secara berlebihan hingga bahkan menyiksa kuli yang mengakibatkan mereka dituduh melakukan pelanggaran terhadap hukum, mereka bisa selamat tanpa harus diadili oleh pengadilan.

Sehingga kehidupan kuli pada masa itu sangatlah sulit. Terkadang kuli juga sangat bodoh, mereka mau saja membawa hasil bekerja mereka ke meja perjudian dan bermain pelacuran, tak jarang mereka juga menghabiskan uangnya dengan menonton wayang, akibatnya mereka harus menandatangani kontrak kerja lagi. Namun hal ini juga dilakukan karena hidup kuli yang sangat membosankan. Sehingga pada akhirnya, para kuli yang seharusnya bisa memenuhi kebutuhan hidupnya bahkan menabung, malah merasa kekurangan bahkan sampai berhutang. Dan hutang inilah yang kemudian menyebabkan para kuli harus menandatangani kembali kontrak kerja dengan pihak perkebunan. Dengan bertambahnya utang, imobilitas kuli kontrak pun bertambah pula. Soalnya, para kuli beranggapan bahwa mereka baru boleh meninggalkan perkebunan apabila mereka sudah tak mempunyai utang lagi. Walaupun masa kontrak lebih panjang dari yang sudah disetujui. 


\section{REFERENSI}

Amirin, M. Tatang. (1996). Pokok-Pokok Teori Sistem. PT RajaGrafindo Persada: Jakarta

Breman, Jan. (1997). Menjinakkan Sang Kuli; Politik Kolonial Tuan Kebun dan Kuli di Sumatera Timur Pada Awal Abad ke-20. Pustaka Utama Grafiti: Jakarta

Daliman, A. (2012). Metode Penelitian Sejarah. Ombak: Yogyakarta.

Fakultas Ilmu Sosial Universitas Negeri Medan. (2013). Buku Pedoman Penulisan Skripsi dan Proposal Penelitian Mahasiswa Program Studi Pendidikan Sejarah. FIS UNIMED

Hasibuan, S. P. Malayu. (2013). Manajemen Sumber Daya Manusia. Bumi Aksara: Jakarta

H.M, Tengku. (1978) . Lintasan Sejarah;Peradaban dan Budaya Penduduk MelayuPesisir Deli Sumatera Timur, 1612-1950. Proyek Penerbitan Buku Bacaan dan Sastra Indonesia dan Daerah: Jakarta

Kartodirdjo,Sartono, dan Joko Suryo. (1991). Sejarah Perkebunan di Indonesia; Kajian Sosial Ekonomi. Aditya Media : Yogyakarta

Lukman, Sinar. (2006). Bangun dan Runtuhnya Kerajaan Melayu di Sumatera Timur. Yayasan Kesultanan Serdang : Medan

Pelzer. J. Karl. (1977). Toean Kebun dan Petani;Politik Kolonial dan Perjuangan Agraria di Sumatera Timur 1863-1947. Sinar Harapan: --

Rachmad, Abdul. (1995). Hukum Perburuhan di Indonesia. Raja Grafindo Persada: Jakarta

Reid, Anthony. (1987) . Perjuangan Rakyat;Revolusi dan Hancurnya Kerajaan di Sumatera.Pustaka Sinar Harapan: Jakarta

Said, Mohammad. (1997). Koeli Kontrak Tempoe Doloe;Dengan Derita dan kemarahannya. Percetakan Waspada :Medan

Simanjuntak, B. A. (2004). Sistem Perpindahan Penguasaan Sawah Pada Masyarakat Toba. Medan: Lembaga Kebudayaan Indonesia.

Sjamsuddin, Helius. (2012). Metodologi Sejarah. Ombak: Yogyakarta

Sugiyono. (2010). Metode Penelitian Kuantitatif Kualitatif Dan $R \& D$. Alfabeta: Bandung.

Winardi. (1989). Pengantar Tentang Teori Sistem dan Analisis Sistem. Mandar Maju: Bandung. 